\title{
THE EFFECTS OF DAYCARE RECONSIDERED
}

\author{
Karen Norberg \\ Working Paper 6769 \\ http://www.nber.org/papers/w6769 \\ NATIONAL BUREAU OF ECONOMIC RESEARCH \\ 1050 Massachusetts Avenue \\ Cambridge, MA 02138 \\ October 1998
}

I would like to thank the NBER for computing and office support, and Josh Angrist, Eli Berman, Janet Currie, Paula DeMasi, Claudia Goldin, Caroline Hoxby, Karen Kuhlthau, Michael LaValley, Steve Pischke, participants in the labor economics lunch seminar at MIT, and other colleagues at the NBER for many valuable comments. A version of this paper was presented at the Meeting of the Well-Being of Children Program of the National Bureau of Economic Research, Cambridge, MA, April 2,1998. The views expressed here are those of the author and do not reflect those of the National Bureau of Economic Research.

(C) 1998 by Karen Norberg. All rights reserved. Short sections of text, not to exceed two paragraphs, may be quoted without explicit permission provided that full credit, including $\mathbb{C}$ notice, is given to the source. 
The Effects of Daycare Reconsidered

Karen Norberg

NBER Working Paper No. 6769

October 1998

JEL No. J13, J22, J23

\section{ABSTRACT}

Do children of employed mothers differ from other children, even before mother's (re)entry to the labor force? Preexisting differences among children may be an alternative explanation for many apparent daycare outcome effects.

Data from the 1994 wave of the National Longitudinal Survey of Youth were available for 6603 singleton infants followed from birth. Mothers of children with intrauterine growth retardation, birth defects, or extended hospitalization at birth began working significantly later after the birth of the child, and mothers of infants with higher development scores and more difficult temperament, and mothers of healthy premature infants, began working significantly earlier. The associations with newborn health persisted when the comparisons were made among siblings.

The magnitudes of the effects were large enough to have practical importance. After controlling for both observed and unobserved differences between families, a mother was only $50 \%$ as likely to have been employed at all in the first five years after the birth of a high risk infant. About $20 \%$ of low-income newborns in the sample were classified as "high risk"; newborn health problems may therefore have resulted in a $10 \%$ lower labor force participation rate among low-income mothers of children under five.

Karen Norberg, MD

Boston University Medical School

and

NBER

1050 Massachusetts Ave.

Cambridge, MA 02138

norberg@nber.org 
c/o NBER; 1050 Massachusetts Ave, Cambridge, MA 02138

\section{THE EFFECTS OF DAYCARE RECONSIDERED}

\section{The transactional process of early daycare:}

Do the children of employed mothers differ from other children, even before mother's entry to employment? If parents seek to protect more vulnerable infants by placing them in fewer hours of substitute care, if mothers seek respite from the care of more "difficult" infants, or if it were easier to find substitute care for "easier" children, then studies in the existing daycare literature may have underestimated, or overestimated, the hazards of substitute care and maternal employment. The present study explores the possibility that infant health, temperament and development may have significant effects on mother's employment.

Economists, psychologists, policy analysts, and parents continue to be concerned about the possible effects of maternal employment on young children. Although several studies have reported a modest cognitive advantage among children in early daycare (eg, Blau and Grossberg, 1992; O'Brien-Caughy et al, 1994, and Burchinal et al, 1997), and other studies have reported a higher rate of behavior problems and insecure infant-mother interactions (eg, Belsky and Eggebeen, 1991; Lamb et al, 1992; Egeland and Heister, 1995; and Clark et al, 1997), design limitations have made it difficult to draw causal inferences from this literature. Mothers who enter the labor force and mothers who remain at home with their young children are known to differ from each other in a number of 
possibly important ways: they may have different skills or abilities; they may be healthy or disabled; they may have access to different resources; and they may have different values and parenting goals. These differences, rather than maternal employment itself, may account for the observed differences among their children. (See Caldwell (1993) and Zazlow et al (1991) for thoughtful reviews).

Could preexisting differences among children, as well as differences among mothers, account for any of the reported effects of daycare? It is likely, based on a number of previous studies, that significant child disability does reduce mother's labor force participation (see Table 1). Could mother's labor force participation also be affected by more common kinds of differences among children?

The present study explores the possible influence of newborn health and infant development and temperament on the timing of mother's first entry to employment after the child's birth. The National Longitudinal Survey of Youth provides a large and diverse sample of children, followed from birth, for whom we have extensive information about mother's employment collected both before and after the child's birth, reports of the child's health status at birth, and developmental assessments in infancy and early childhood. We consider four specific indicators of the child's health at birth (prematurity, presence of birth defect, nutritional status, and length of hospitalization at birth), and mothers' ratings of the child's development and fearful and difficult temperament in infancy, as predictors of the timing of mother's first (re)entry into the labor force after the child's birth. Unlike previous studies, we distinguish the effects of prematurity from the effects of 
intrauterine growth retardation; we control for mother's work history before the child's birth; and we further control for unobserved maternal background factors, by making comparisons among siblings within the same family. Because infancy ratings might be affected by the child's daycare experience, we compare the predictions from infant development and temperament in the sample as a whole, to the subset of children whose assessments took place before mother's return to work.

\section{Parental investment and the intrahousehold allocation of resources:}

A child's health, development or temperament could influence mother's employment in several ways. Most obviously, the child's health or temperament could contribute to the child's observed well-being in maternal versus substitute care (Rosenzweig and Schultz, 1983; Becker and Lewis, 1973; Becker and Tomes, 1976; Blau \& Robins, 1989). The child's attractiveness to her parents could affect the pleasure which the parents experience when spending time with her (Bell, 1971; Ritter, Casey, and Langlois, 1991); and the child's attractiveness to other caretakers could affect the cost or the availability of substitute care. The child's health, and the gender mix of children already in the family, could influence whether parents choose to have another child (Rosenzweig and Wolpin, 1988; Altmann, et al, 1978; Angrist and Evans, 1996); and one or both parents of significantly disabled children may be tempted to abandon the parenting role altogether (Corman and Kaestner, 1992). 
Table 1 presents a summary of fifteen empirical studies which have considered whether child characteristics may influence maternal employment. Many of these studies have found that child health problems reduce the likelihood of mother's employment, but the health or disability measures used in these studies have referred to no more than about $6 \%$ of children in the general population. Many daycare studies have excluded disabled children in order to control for this potential bias. Child gender has been examined most convincingly by Angrist and Evans (1996); they find that, in families with at two children, the gender mix of the existing children may affect mother's later employment by influencing the likelihood that a couple will choose to have a third child; however, child gender itself did not predict maternal employment. Except for child gender, only three of the studies in Table 1 have considered the possible influence of more common or "normal" differences among children. Galambos and Lerner (using a sample from the 1950's) find that mothers of "difficult" toddlers were less likely to be working in the child's toddler or preschool years; in contrast, Greenberger and O'Neill (using a sample from the 1980's) find that mothers of "difficult" preschoolers were more likely to be working at kindergarten age; Vaughn, Gove, and Egeland (1980) report no association between neonatal behavior assessment scores and mother's employment status in the first two years. All three of these studies are based on very small samples.

Both economists and evolutionary biologists have proposed formal theoretical models considering how child characteristics might influence the intra- 
household allocation of resources (Becker and Tomes, 1976; Hanushek, 1992;

Thomas, 1990; Rosenzweig and Wolpin, 1988; Trivers, 1974). When the marginal utility of parental care is higher for the more vulnerable child, then utilitymaximization models predict that parental resources (for example, mother's time) will be distributed so as to provide additional units of care for the more vulnerable child. Infants reward their parents, at least in part, through occasions of physical affection and social interaction which parents experience as joyful and loving; "easy" infants may be more rewarding than others. If these attractions fail, infants may also attempt to enforce parental attention through the judicious use of crying and tantrums; "difficult" infants may be more demanding than others. If the marginal cost of parental care, to the parent, is higher for the more "difficult" child, then the "difficult" child may receive fewer units of care. Although the simplest models of parental investment have considered the household as a single decisionmaking unit, more complex models of parental investment have considered the parent-offspring relationship as a bargaining process, with the possibilities of intergenerational cooperation or conflict, communication or deception (Trivers, 1974; Maynard-Smith, 1977).

There are several corollaries to the utility-maximization model that have non-trivial implications for competing siblings. Children of different ages may benefit from different kinds of parental input; younger children are often perceived as benefiting the most from direct parental contact. In general, if parental time investments are guided by milestones which are eventually within reach for most 
children (for example: "I will return to work when my child is sleeping through the night"), then the "mature" child who achieves a milestone more quickly may receive fewer time resources (for example, a shorter maternity leave) because the target for parental investment has been reached sooner. This is not the only possible parental strategy; under other circumstances (for example, under conditions of very high variation in possible child outcome) parents might prefer to invest in the children who are most likely to do well. (Hanushek, 1992; Rosenzweig \& Wolpin, 1988; Becker and Tomes, 1976).

\section{Design of the present study:}

The sample for the present study is drawn from the 1994 wave of the 1979 National Longitudinal Survey of Youth. The NLSY79 began as a sample of young men and women who were between the ages of 14 and 21 in 1979, with an oversampling of black, hispanic, and low-income white subjects. Since 1982, the survey has collected systematic information about the children of female subjects, including pregnancy and birth history, mother's work status coded quarterly from 12 months before the child's birth to five years after birth, and the exact dates of stopping and starting work (if any) before and after the child's birth. At the time of this study, the 1994 wave of interviews were the most recent available. Extensive descriptions and documentation of the NLSY are available (Center for Human Resource Research: NLS Users' Guide, 1994).

The eligible subjects for this report consisted of all singleton infants who were 
born after the mother's entry into the survey, and for whom we had complete records of the birth factors and background variables selected for study. The final sample consisted of 6603 infants born to 3785 mothers between 1980 and 1994; mothers in the sample were between 14 and 36 years old at the time of their children's births. Of this full sample, 5727 children (from 2782 families) had at least one older or younger sibling also in the sample. Beginning in 1986, the NLSY has undertaken periodic assessments of the children's cognitive and social development; about $73 \%$ of children born after 1985 have had an initial assessment before the age of 24 months. 1162 children, about $40 \%$ of the development sample, were assessed before mother's entry to employment. Tables 2 and 3 present a description of the full, sibling, and development samples.

\section{Mother's work history and return to employment:}

$90 \%$ of mothers in the sample had worked at some time before the child's birth, and $87.1 \%$ of mothers were observed to have worked at some time after the child's birth. For the purposes of the present study, we are interested in the timing of mother's first entry to employment after the child's birth. We choose this outcome measure because of its conceptual clarity, and because of the high quality of the information about the timing of employment available within the NLSY.

\section{Child factors:}

Children's birth characteristics are of particular interest in the present study, 
because they are observed before the beginning of the child's post-natal care. The birth information available in the NLSY allows us to distinguish among four newborn health characteristics: prematurity (based on the reported gap between the infant's date of birth and expected due date); intrauterine growth retardation (IUGR; based on comparisons of the child's birth weight with standards adjusted for the child's gender, ethnicity, and gestational age); congenital defect (based on the reported results of prenatal testing); and the child's length of hospitalization at birth (compared to mother's length of hospitalization). Because the patterns of prediction from birth defect, IUGR, and extended hospitalization were observed to be very similar, these three characteristics were collapsed into a single "high risk" category (coded 0 or 1 ) for the purpose of most analyses.

The Motor and Social Development Scale and the Temperament Scale of the NLSY consist of maternal report items derived from several well-known measures of early child development (the Bayley, Gesell, and Denver, and the Rothbart Infant Behavior Questionaire). Norms were established using the same instruments in the 1981 National Health Interview Survey.

The NLSY Temperament Scale contains three subscales: fearfulness, positive affect, and what the developers have labeled "friendliness"; all three subscales are moderately to highly correlated. Because we were interested in examining the differential parental response to "fearfulness" vs. other negative affect, we retained "fearfulness" as a separate scale, and combined positive affect and "friendliness", with the necessary reverse codings, into a "difficulty" scale. 
The development scale yields a single, age- and gender-standardized score, with a mean of 100 and a standard deviation of 15 . Both the temperament and the development scores have been transformed in our regression models into z-scores, with a mean of zero, and standard deviation of one.

\section{Maternal and household background factors:}

Ten other maternal and family background variables, assessed before the child's birth, were also considered as possible predictors of maternal employment. These study variables are summarized in Table 3 , and the definitions of the variables are presented in more detail in Appendix B. We have focused on factors that could not, themselves, have been influenced by the infant's characteristics. As a result, we have omitted several potentially important factors, such as the arrival of younger siblings, mother's health after pregnancy, and father's continued presence in the household, which may influence mother's labor force participation, but which refer to events that occur after the child's birth.

\section{RESULTS:}

\section{Part 1: Do birth factors predict the timing of mother's employment?:}

Fifty percent of mothers in the sample had returned to work by 34 weeks; 55.5\% were employed within the first year of the child's life, and $86.7 \%$ were employed at some time in the first five years. Mothers of infants with IUGR, birth defects, or extended hospitalizations began working at a median of 47 weeks, or 
about 13 weeks later than the mothers of healthy infants. Unexpectedly, mothers of premature infants began working at a median of 27 weeks, about seven weeks earlier than the mothers of full term infants. Figure 1 presents the simple survival curves, comparing the cumulative proportions of mothers still remaining at home for up to 15 years after the child's birth, for full term and preterm infants, both healthy and high risk; Figure 2 compares infants with birth defects, IUGR, and extended hospitalizations.

Table 4 summarizes the results of several Cox proportional hazard regression models, estimating the joint contribution of child and maternal factors in predicting the likelihood of mother's entry into the labor force after the child's birth. The proportional hazard regression predicts the instantaneous likelihood of mother's entry to employment at time ( $\mathrm{t}$ ), among mothers who are not yet working at that time. For some analyses, we also report the results of logistic regression models (otherwise similar to the proportional hazard regressions) predicting the likelihood of mother ever having worked within the first five years after the child's birth. In both types of regression, for any parameter value $\mathrm{p}$, an increase of one unit in the associated factor multiplies the likelihood of employment by $\mathrm{e}^{\mathrm{p}}$.

In Table 4, model 1 presents the parameters associated with infant birth characteristics, considered as a group without maternal factors; model 2 adds maternal background variables; model 3 is similar to model 2, but combines IUGR, birth defect, and extended hospitalization into a single "high risk" category, and model 4 includes all of the significant two-way interactions which emerged among 
factors in model 3.

When the child health factors were considered together in model 1 of Table 4, mothers of infants with intrauterine growth retardation and extended hospitalizations were 15 to $21 \%$ less likely to begin working at any interval, compared to other mothers, and mothers of healthy premature infants were $9.4 \%$ more likely to begin working than other mothers. After controlling for mother's pre-pregnancy employment and other factors in models 2 and 3, it appears that mothers of high risk infants were about $13 \%$ less likely to begin working at any interval, (and about 55\% less likely to work at all in the first five years), compared to other mothers. Mothers of healthy premature infants were about $13 \%$ more likely to begin work at any interval, and $32 \%$ more likely to ever work in the first five years. Figures 1 and 2 suggest that the associations with prematurity and newborn "high risk" status persist well after children have reached school age.

As we expected, mother's past work history was by far the strongest predictor of mother's employment after the child's birth. Mother's health status, AFQT, ethnicity, and poverty status and receipt of public support were also significant predictors; child "risk" status and maternal health had effects of similar magnitude. Prematurity predicted earlier employment most strongly among mothers with the highest and lowest AFQT scores, (see Figure 3), and infant risk status predicted later employment more strongly among hispanic mothers (Figure 4).

Hazard regressions similar to models 3 and 4 were used to predict the 
timing of mother's leave from work before the infant's birth. The unexpectedly shortened maternity leave after the birth of a healthy premature infant could not be explained as a consequence of a longer leave-from-work before birth: mothers of premature infants not only began working earlier than other mothers, but they had left work significantly closer to the time of delivery (risk ratio 1.09, $\mathrm{p}=.05$ ).

\section{Part 2: Within-family fixed effects:}

An association between the child's birth characteristics and mother's employment does not establish whether the child's characteristics are truly "causing" mother's employment decision. For example, low income mothers are more likely to have "high risk" infants. If mothers of high risk infants are less likely to work that other mothers, this could reflect the effects of poverty, poor education, and other obstacles to employment opportunity for these mothers, regardless of the health status of the infant. As another example, premature birth might increase the likelihood of mother's employment, perhaps by influencing the affective relationship between mother and infant, but it is also possible that unobserved characteristics of the mother could simultaneously increase the risk of prematurity, and increase the likelihood of an early return to employment after the child's birth.

We can control for many unobserved maternal background factors by making comparisons among children in the same family. Our second analysis considers whether within-family differences in newborn health among siblings 
predicted within-family differences in the timing of mother's return to work after each birth. We use a conditional logistic model to describe the timing of mother's employment; this model takes the difference between mother's observed work status at specific intervals after the child's birth, and the mean of that observation at comparable intervals among all siblings within the family. Factors within the family which would not vary from one birth to the next - factors such as mother's own childhood and ethnic background, AFQT score and general abilities, and personal and work experience before the birth of her first child - will drop out of the equation. Other environmental factors - such as the child's birth order, father's presence in the home, and mother's age, health, and most recent work status before pregnancy - may vary across siblings; if measured, these factors are kept in the model. There is a potential bias in the fixed-effect model if the health of one sibling can affect the likelihood of mother's employment after the birth of other siblings. For example, if a second sibling is born before mother has returned to work after the birth of a first sibling, then mother's time-to-work for both children could be influenced by the health of either child. 9.5\% of sibling pairs had overlapping timeto-work intervals in the present sample; premature infants were less likely, and high risk infants were more likely to be part of overlapping intervals. Overall, the occurence of overlapping observations among siblings would have tended to underestimate the effects of "high risk" status in the fixed effects model.

Table 5 compares ordinary and conditional logistic regressions, predicting whether mother had ever begun employment by one, two, three, four and five 
years after the child's birth. The first two rows of table 5 present the parameters associated with prematurity and "high risk" status in ordinary logistic regression models; child gender (which was not significant) and all maternal background factors were also included in these models, but, for simplicity, these parameters are not presented in the table. The third and fourth rows of the table present the comparable conditional logistic models comparing the prediction to maternal employment among siblings within the same family. Child gender and birth order, father's presence, and mother's age, health status, and work hours before pregnancy were included in these models; again, for simplicity, only prematurity and risk status are presented.

In the fixed effects model, after the second year, we find that high risk status remains strongly significant in the fixed-effects model, but we find that prematurity falls away. Mothers were only about half as likely to have ever worked within five years after the birth of a high risk infant, compared to the child's normal sibling. Mothers of premature infants began to work earlier, but prematurity did not predict differences in maternal employment among siblings; instead, it is as if the mothers of premature infants were more "hurried" in returning to work after the births of both the premature infant and the infant's fullterm siblings.

\section{Part 3: Development and temperament:}

In the next step of our analysis, we examine whether infant development and temperament seem to predict mother's employment. These assessments were 
available for 2841 children, including 1162 children for whom the infant assessments happened to have taken place before mother was yet working. Children were more likely to be in the "not yet working" subgroup if their mothers entered employment later rather than earlier; as a result, children in this subgroup were more likely to be high risk than children in the "already working" subgroup (18\% vs $12.75 \%$ ), with lower development scores (mean 99 vs 102.5$)$ and higher difficulty scores (mean 6.0 vs. 5.6); their mothers were less likely to have been working before pregnancy ( $41.1 \%$ vs $85.7 \%$ ), more likely to be hispanic (20.6\% vs $16.6 \%)$, more likely to be in poverty, (39.9\% vs $15.2 \%)$, more likely to have been on public support ( $34.0 \%$ vs $11.3 \%)$, and more likely to be single (28.55 vs $20.0 \%$ ). Because they are a selected group, the estimates from this subsample may not represent the experience of children in the NLSY as a whole; all the same, the patterns of prediction in this subsample cannot be directly attributed to mother's employment.

Figure 3 presents the simple survival curves associated with infant development and fearful and difficult temperament. Table 6 compares a series of hazard models predicting mother's employment as a function of infant development and temperament. Model 1 considers the prediction from infant factors alone; model 2 adds maternal background factors, model 3 adds all significant interactions involving child factors, and models 4 and 5 resemble models 2 and 3, conditional on mother's not yet having returned to work at the time of the child's assessment. 
In all of the models, higher development scores predicted earlier maternal employment, and the response to perceived infant fearfulness seemed to differ from the response to perceived infant difficulty. In general, difficult temperament predicted a higher likelihood of maternal employment; the trend illustrated in figure 3 becomes larger in magnitude, and statistically significant, after the inclusion of maternal background factors. Fearful temperament predicted a lower likelihood of maternal employment, but becomes less significant after the inclusion of maternal background. The association with the child's development score changed little in the "not yet working" subgroup, but the associations with fearfulness and with difficult temperament became much stronger.

There were a number of interactions observed between the child and maternal factors. For example, models 3 and 5 reveal a complex, three-way interaction among child gender, mother's work status before pregnancy, difficult temperament, and the likelihood of employment after birth. Among mothers who were not working before pregnancy, high difficulty scores were associated with a later entry to work, especially for boys. Among mothers who did work just before pregnancy, high difficulty scores were associated with an earlier return to work, especially for boys. High difficulty scores were also stronger predictors of an earlier return to work among mothers of premature infants.

The interaction between difficult temperament and mother's past work status seemed to be specific to mother's labor force attachment, and was not paralleled by interactions between difficult temperament and other factors related 
to mother's general abilities or expected wage, such as age, education, AFQT score, or ethnicity.

There were also interactions between maternal AFQT and infant fearfulness and child gender. Mothers with the highest and lowest AFQT scores appear to be more responsive to infant fearfulness than mothers with intermediate scores;

mothers with lower AFQT scores were more likely to stay at home with daughters, and mothers with higher AFQT scores were more likely to stay at home with sons. Figure 4 illustrates this interaction.

\section{Part 5: Prediction from mother's employment to children's behavior problems at kindergarten age:}

In the last step of our analysis, we examine mother's cumulative hours of work over the first four years as a predictor of the mother's ratings of the child's behavior problems at kindergarten age, - not as a definitive analysis, but to examine the degree to which such estimates might be influenced by the maternal and child endowment factors considered in the present study.

The Behavior Problems Index (BPI) consists of 28 maternal report items; like the infant assessments, age specific national norms for this index were established in the 1981 National Health Interview Survey. Higher scores on the BPI reflect more behavior problems; the sample mean score is 104 , with a standard deviation of 14.8. 1805 children in the development sample received a Behavior Problems Index rating between 4 and 6 years of age. 
Table 7 presents four ordinary linear regression models predicting the child's Behavior Problem Index scores at kindergarten age. The first model in Table 7 predicts the child's BPI score from the "employment effect" measure, mother's average hours per week of employment over the child's first four years, and selected maternal background measures, including mother's age, poverty status, and the child's firstborn status. Model 2 adds maternal background factors which are less commonly available in other data sets: mother's AFQT, mother's health before the child's birth, and lagged employment. Model 3 adds child health, gender, development, and fearful temperament; and model 4 adds difficult temperament. From model 1 to model 2, the added maternal background factors increased the estimated effect of mother's employment by about $22 \%$, and from model 2 to model 3, infant health, development and fearfulness scores increased the effect by about $20 \%$; in model 4 , difficult temperament decreased the apparent effect by about $14 \%$. The apparent negative effect of maternal employment remains small, but significant; for example, in the final model, forty hours work per week over the first four years of the child's life predicted an increase of 2.4 points in the child's behavior problem score at kindergarten age, compared to children whose mothers did not work. The employment-effect estimate appears to be about equally sensitive to the maternal and infant factors which are included in the model.

\section{DISCUSSION:}

Mothers were $55 \%$ less likely to have worked in the first five years after 
the birth of a "high risk" infant. Mothers of healthy premature infants were about $33 \%$ more likely to have worked, mothers of more difficult infants were about $23 \%$ more likely to have worked, and mothers of infants with lower development scores were about $19 \%$ less likely to have worked in the first five years.

Can we conclude that common variations in child health, temperament, or development truly "cause" differences in mother's labor force participation? On the one hand, it seems plausible that parents may adapt to individual differences among children, and the apparent large effects of newborn "high risk" status remained significant in the comparisons among siblings. On the other hand, the association with prematurity disappeared in the fixed-effects model, and the sample was too small to test a sibling model for development and temperament. Some of these child endowments may have directly influenced mother's employment; others (for example, prematurity) probably did not. All the same, the design of the present study does establish that children in daycare may differ from other children, well before their entry into daycare.

The selection effects reported here closely match the pattern of child characteristics which have been interpreted as daycare or employment outcomes in previous studies. In the present study, mothers of high risk and developmentally delayed infants were slower to return to employment; it is possible that the cognitive benefits of maternal employment may have been overstated. The mothers of more "difficult" infants usually began working earlier than other mothers; the behavioral hazards of maternal employment may also have been overstated. 
Mothers of difficult boys returned to work earlier than mothers of difficult girls, and mothers with lower AFQT scores were more likely to work if the child was a boy; preexisting differences in maternal ability and infant temperament may explain some reported gender differences in daycare outcome (Rutter, 1981;

Bronfenbrenner et al, 1984; Gamble and Zigler, 1986; Goldsmith and Alansky, 1987; Hoffman, 1989, Desai et al, 1989, and NICHD, 1997.)

The interactions among difficult temperament, child gender, and mother's previous work status can be summarized by stating that mothers of difficult infants, especially difficult boys, were most likely to resume their previous employment status after the child's birth: mothers who were working before pregnancy, returned to work sooner, and mothers who were at home before pregnancy, remained at home longer. This interaction was not explained by any interactions between child temperament and other factors (such as maternal age, ethnicity, education, or AFQT score) that are also associated with employment. Thus, it seems that difficult infant temperament has a direct effect on the costs or benefits of maternal role change itself. For example, the stress of caring for a difficult infant could cause a mother to place a higher value on her existing social supports; if she has been working, these supports may be in the workplace, and if she has been at home, these supports may be near home. Whatever the underlying process, recent studies have suggested that for mothers who do seek respite from the care of a "difficult" infant, the respite may have a protective effect for the parent-child relationship (Egeland and Hiester, 1995). 
Maternal or child selection effects could reconcile several conflicting or "paradoxical" results in the existing daycare literature. Lamb, Sternberg, and Prodromidis (1992), in a comprehensive metaanalysis of daycare-related attachment studies published up to that date, found that toddlers in part-time daycare were 6.7 times more likely to be rated as insecure than children in full-time daycare, and Baydar and Brooks-Gunn (1991) find that children in part-time daycare have lower vocabulary scores at four years than children in full-time home care or full-time daycare. If the care of difficult infants were more likely to be divided among multiple caregivers, or if mother's hours per week of employment were affected by factors that differed from those affecting her decision to enter the labor force, then children in part-time care could be more vulnerable, before their entry into daycare, than children in either home care or full-time daycare.

In practice, how important do the observed effects appear to be? From the point of view of the high risk infant, the effects are large: mothers were half as likely to have worked within five years after the birth of a high risk infant, and mothers of infants with high difficulty scores were a third more likely to have worked in the first five years. From an economic standpoint, the observed effects may also be significant. Low income infants have higher rates of health problems; we found that $20 \%$ of low-income children were classified as "high risk" in the present study. This $20 \%$ prevalence predicts a $10 \%$ lower rate of labor force participation among low-income mothers than would otherwise have been observed. 
Table 7 suggests that estimates of the behavioral effects of daycare may be sensitive to the exact child and maternal factors considered in the estimation model. The magnitude of the estimate was increased by up to $20 \%$ by the inclusion of our child variables; this was similar to the estimate's sensitivity to the inclusion of maternal health, AFQT, and past employment. Taken together, the child variables (including difficult temperament) increased the magnitude of the estimate by less than $4 \%$, but the final model in Table 7 predicted only $11 \%$ of the variance in the child's BPI score, and a regression model using all of our child and maternal variables explained less than one third of the variance in mother's cumulative hours employed by four years. Other child outcomes - for example, security of attachment - may be affected to different degrees by preexisting differences among mothers and children. Other child measures - for example, more refined assessments of newborn neurodevelopmental status and health, and other measures of infant development, physical maturity, and physical and social attractiveness may prove to be stronger predictors of parental behavior.

\section{Policy Implications:}

The evidence reported here may have implications for family leave policy, welfare reform and social security reform, as well as for the interpretation of the existing maternal employment, preschool education and daycare literatures. Mothers do seem to be influenced by their children's health and wellbeing, and these influences seem to go beyond the effects of childhood "disability", as usually 
defined. The current cutbacks in income support for low-income families may significantly affect the elasticity of mother's labor supply in response to child vulnerability. If the parental choices observed in the present study do tend to benefit children, then withdrawal of public support for low-income mothers may harm those children who face the greatest developmental hazards.

The evidence reported here also supports the use of experimental study designs (or the use of instrumental variable techniques) to assess the impact of important policy interventions on the family. The determinants of maternal employment are still poorly understood; observational studies (such as the NLSY) are likely to be able to "control" for only a small portion of the factors which may influence the interactions between parents and children.

\section{Conclusions:}

Newborn health, infant development and infant temperament predict mother's labor force participation. Mothers of "small for dates" and other high risk infants are only about half as likely to be employed in the first five years, and mothers of premature infants, mothers of infants with higher development scores, and mothers of infants perceived as having more difficult temperament are 20-33\% more likely to be employed in the first five years, compared to mothers of other children. It appears likely that child health and wellbeing do influence mother's labor force participation, but whether or not we have measured the most important child factors influencing mother's employment, and whether or not this association 
represents a causal relationship, our results suggest that the children of employed mothers may differ significantly from other children, well before their entry into daycare. This observation may have policy implications for AFDC and children's social security reform, and should be considered as an alternative explanation for many apparent daycare outcome effects. 
Table 1: Does child quality influence mother's labor force participation?:

Summary of previous studies explicitly testing for child selection effects:

\begin{tabular}{|c|c|c|c|c|c|c|}
\hline Authors & year & sample & $\mathrm{n}$ & $\begin{array}{l}\text { child } \\
\text { factor }\end{array}$ & $\begin{array}{l}\text { age } \\
\text { range }\end{array}$ & results \\
\hline Angrist \& Evans & 1996 & PUMS & 274,809 & gender & $0-18$ yrs & $\begin{array}{l}\text { n.s. (but same-sex } \\
\text { sibs }=\text { less } \% \text { work) }\end{array}$ \\
\hline Wolfe \& Hill & 1992 & SIPP & 20,000 & disabil. & $0-18$ yrs & less \% work \\
\hline Salkever & 1982 & NHIS & 13,128 & disabil. & $0-17$ yrs & less \% work \\
\hline Breslau et al & 1982 & & 456 & disabil. & $3-18$ yrs & less \% work \\
\hline Landis & 1992 & & 65 & disabil. & $0-3$ yrs & fewer hr/wk \\
\hline Blau \& Grossberg & 1992 & NLSY & 874 & low bwt & $0-5$ yrs & less $\%$ work \\
\hline Belsky \& Eggebeen & 1991 & NLSY & 664 & $\begin{array}{l}\text { low bwt, } \\
\text { preterm }\end{array}$ & $0-3$ yrs & n.s. \\
\hline Mott & 1991 & NLSY & ? & health & $0-1 \mathrm{yr}$ & less daycare \\
\hline Galambos \& Lerner & 1987 & NYLS & 93 & $\begin{array}{l}\text { health, } \\
\text { temp'mnt }\end{array}$ & $0-6$ yrs & $\begin{array}{l}\text { health prob., } \\
\text { diff. tmpt= } \\
\text { less \% work }\end{array}$ \\
\hline Greenberger \& O'Neil & 1992 & & 153 & temp'mnt & $4-6 \mathrm{yrs}$ & $\begin{array}{l}\text { diff. tmpt }= \\
\text { more \% work }\end{array}$ \\
\hline Vaughn, Gove \& Egeland & 1980 & & 104 & $\begin{array}{l}\text { health, } \\
\text { dev'mnt }\end{array}$ & $\begin{array}{l}0-1.5 \\
\text { yrs }\end{array}$ & $\mathrm{n} \cdot \mathrm{s}$ \\
\hline
\end{tabular}

Abbreviations:

bwt $=$ birth weight

dev'mnt = development

diff.tmpt.= difficult temperament

disabil. = disability

NHIS = National Health Interview Survey

NLSY = National Longitudinal Survey of Youth 
NYLS $=$ New York Longitudinal Survey

PUMS = Public Use Micro-Sample (from US Census)

SIPP = Survey of Income and Program Participation 
Table 2:

Sample Description:

Child Characteristics

\begin{tabular}{|c|c|c|c|c|}
\hline Variable: & $\begin{array}{l}\text { Whole } \\
\text { Sample }\end{array}$ & $\begin{array}{l}\text { Sibling } \\
\text { Sample }\end{array}$ & $\begin{array}{l}\text { Dev'mnt } \\
\text { Sample }\end{array}$ & $\begin{array}{l}\text { Dev'mnt } \\
\text { Sample } \\
\text { "Not yet } \\
\text { working" }\end{array}$ \\
\hline $\begin{array}{l}\text { Number of Children: } \\
\text { Number of Families: }\end{array}$ & $\begin{array}{l}6603 \\
3785\end{array}$ & $\begin{array}{l}5727 \\
2908\end{array}$ & $\begin{array}{l}2841 \\
2156\end{array}$ & $\begin{array}{r}1162 \\
949\end{array}$ \\
\hline \multicolumn{5}{|l|}{ At Birth: } \\
\hline Female: & $48.8 \%$ & $48.6 \%$ & $48.4 \%$ & $46.1 \%$ \\
\hline High Risk: & $16.3 \%$ & $16.1 \%$ & $14.8 \%$ & $18.0 \%$ \\
\hline $\begin{array}{l}\text { Intrauterine Growth } \\
\text { Retardation: }\end{array}$ & $5.9 \%$ & $5.9 \%$ & $4.9 \%$ & $6.5 \%$ \\
\hline $\begin{array}{l}\text { Extended Hosp'n at } \\
\text { Birth: }\end{array}$ & $10.9 \%$ & $10.6 \%$ & $9.6 \%$ & $11.5 \%$ \\
\hline Birth Defect Noted: & $1.5 \%$ & $1.5 \%$ & $2.2 \%$ & $2.9 \%$ \\
\hline Premature: & $11.0 \%$ & $10.7 \%$ & $10.2 \%$ & $9.4 \%$ \\
\hline Preterm, Low Risk: & $6.5 \%$ & $6.4 \%$ & $5.9 \%$ & $4.9 \%$ \\
\hline Preterm, High Risk: & $4.5 \%$ & $4.3 \%$ & $4.3 \%$ & $4.5 \%$ \\
\hline Age $0-24$ Months: & & & & \\
\hline Development: & & & $\begin{array}{l}101.0 \\
(16.6)\end{array}$ & $\begin{array}{l}99.0 \\
(18.1)\end{array}$ \\
\hline Difficult Temperament: & & & $\begin{array}{l}5.8 \\
(1.9)\end{array}$ & $\begin{array}{c}6.1 \\
(2.0)\end{array}$ \\
\hline Fearful Temperament: & & & $\begin{array}{l}8.6 \\
(3.8)\end{array}$ & $\begin{array}{l}8.7 \\
(3.8)\end{array}$ \\
\hline Age 4-6 Years: & & & & \\
\hline Behavior Problems Index: & & & $\begin{array}{l}104.0 \\
(14.8)\end{array}$ & $\begin{array}{l}104.0 \\
(21.4)\end{array}$ \\
\hline
\end{tabular}

Standard deviations are in parentheses. 
Table 3:

Sample Description :

Mother and Household Background Characteristics

\begin{tabular}{|c|c|c|c|c|}
\hline Variable: & $\begin{array}{l}\text { Whole } \\
\text { Sample: }\end{array}$ & $\begin{array}{l}\text { Sibling } \\
\text { Sample: }\end{array}$ & $\begin{array}{l}\text { Dev'ment } \\
\text { Sample: }\end{array}$ & $\begin{array}{l}\text { Dev 'ment } \\
\text { Sample, } \\
\text { "Not yet } \\
\text { working" : }\end{array}$ \\
\hline Number of Children: & 6603 & 5727 & 2841 & 1162 \\
\hline Number of Families: & 3785 & 2908 & 2156 & 949 \\
\hline $\begin{array}{l}\text { Ever Worked Before Child's } \\
\text { Birth : }\end{array}$ & $90.0 \%$ & $89.8 \%$ & $96.5 \%$ & $92.2 \%$ \\
\hline $\begin{array}{l}\text { Working 9-12 Months Before } \\
\text { Birth: }\end{array}$ & $60.6 \%$ & $58.7 \div$ & $67.4 \%$ & $41.1 \%$ \\
\hline $\begin{array}{l}\text { Mean Hrs/Wk Worked 9-12 } \\
\text { Months Before Child's Birth: }\end{array}$ & $\begin{array}{c}21.9 \\
(19.9)\end{array}$ & $\begin{array}{l}21 \cdot 0 \\
(19.8)\end{array}$ & $\begin{array}{l}24.9 \\
(19.8)\end{array}$ & $\begin{array}{c}14.3 \\
(19.1)\end{array}$ \\
\hline $\begin{array}{l}\text { Ever Working By } 24 \text { Months } \\
\text { After Child's Birth: }\end{array}$ & $69.2 \%$ & $65.9 \div$ & $71.9 \%$ & $31.4 \div$ \\
\hline $\begin{array}{l}\text { Ever Working From Child's } \\
\text { Birth to } 1994 \text { interview: }\end{array}$ & $87.1 \%$ & $87.1 \%$ & $85.4 \div$ & $35.6 \%$ \\
\hline $\begin{array}{l}\text { Median Weeks since Last } \\
\text { Worked Before Child's Birth: }\end{array}$ & 22.0 & 32.0 & 9.0 & 61.5 \\
\hline $\begin{array}{l}\text { Median Weeks To Labor Force } \\
\text { Entry After Child's Birth: }\end{array}$ & 34.0 & 45.4 & 20.0 & 151.0 \\
\hline $\begin{array}{l}\text { Mean Hours Per Week Worked } \\
\text { Over First Four Years: }\end{array}$ & $\begin{array}{l}14 \cdot 6 \\
(14.3)\end{array}$ & $\begin{array}{c}12.8 \\
(13.5)\end{array}$ & $\begin{array}{c}16.5 \\
(14.9)\end{array}$ & $\begin{array}{l}5.6 \\
(8.9)\end{array}$ \\
\hline Mom has Health Problem: & $19.5 \%$ & $19.5 \%$ & $18.7 \%$ & $21.5 \%$ \\
\hline Black Ethnicity: & $27.1 \%$ & $27.6 \%$ & $26.4 \%$ & $25.9 \%$ \\
\hline Hispanic Ethnicity: & $18.5 \%$ & $19.4 \%$ & $18.3 \%$ & $20.6 \%$ \\
\hline $\begin{array}{l}\text { Age At Child's Birth } \\
\text { (years): }\end{array}$ & $\begin{array}{l}24.0 \\
(3.9)\end{array}$ & $\begin{array}{l}24.0 \\
(3.9)\end{array}$ & $\begin{array}{l}26.4 \\
(3.2)\end{array}$ & $\begin{array}{l}26.2 \\
(3.2)\end{array}$ \\
\hline AFQT Score, 1980 : & $\begin{array}{c}617 \\
(216)\end{array}$ & $\begin{array}{c}589 \\
(217)\end{array}$ & $\begin{array}{c}640 \\
(215)\end{array}$ & $\begin{array}{c}580 \\
(223)\end{array}$ \\
\hline Male Partner in Home, Yr 0: & $69.2 \%$ & $69.5 \%$ & $76.5 \%$ & $71.5 \%$ \\
\hline Rec'd Public Support, Yr 0: & $20.4 \%$ & $22.8 \%$ & $20.6 \%$ & $34.0 \%$ \\
\hline Below Poverty, Yr 0 : & $27.5 \%$ & $29.4 \%$ & $25.3 \%$ & $40.0 \%$ \\
\hline Child is Firstborn: & $44.0 \%$ & $35.4 \%$ & $36.1 \%$ & $24.6 \%$ \\
\hline
\end{tabular}

Standard deviations are in parentheses.

Year $0=$ calendar year before child's birth 


\begin{tabular}{|c|c|c|c|c|}
\hline $\mathrm{n}=6603$ & $\begin{array}{l}\text { Model 1: } \\
\text { infant } \\
\text { only }\end{array}$ & $\begin{array}{l}\text { Model } \mathbf{2 :} \\
\text { maternal } \\
\text { and infant }\end{array}$ & $\begin{array}{l}\text { Model 3: } \\
\text { using } \\
\text { "high risk" }\end{array}$ & $\begin{array}{l}\text { Model 4: } \\
\text { with } \\
\text { int'ns }\end{array}$ \\
\hline IUGR & $-.22(.06) *$ & $-.12(.06) *$ & & \\
\hline Hosp'n & $-.17(.05) *$ & $-.12(.05) *$ & $-.14(.04) *$ & $-.09(.04) *$ \\
\hline Bth Dfet & $-.11(.11)$ & $-.17(.11)$ & & \\
\hline Preterm & $.10(.04) *$ & $.14(.04) *$ & $.14(.04) *$ & $.04(.06)$ \\
\hline Female & $.02(.03)$ & $.01(.03)$ & $.01(.03)$ & $.01(.03)$ \\
\hline Hisp. x Rsk & & & & $-.24(.09) \star$ \\
\hline $\mathrm{AFQT}^{2}$ x Pre. & & & & $.10(.04) *$ \\
\hline Last Wkd & & $-.12(.01) \star$ & $-.12(.01) \star$ & $-.12(.01) \star$ \\
\hline lagged $\mathrm{Hr} / \mathrm{Wk}$ & & $.05(.01) \star$ & $.05(.01) *$ & $-.05(.01) \star$ \\
\hline Mom Hlth Prb. & & $-.13(.03) \star$ & $-.13(.03) \star$ & $-.13(.03) \star$ \\
\hline Black & & $.28(.04) \star$ & $.28(.04) *$ & $.28(.04) \star$ \\
\hline Hispanic & & $.12(.04) \star$ & $.12(.04) *$ & $.15(.04) *$ \\
\hline Mo's Age & & $.005(.006)$ & $.004(.004)$ & $-.01(.01)$ \\
\hline Firstborn & & $-.07(.03)$ & $-.07(.03) \star$ & $-.07(.03) \star$ \\
\hline Partner & & $.05(.03)$ & $.05(.03)$ & $.04(.03)$ \\
\hline $\mathrm{AFQT}$ & & $.16(.02) \star$ & $.18(.02) *$ & $.10(.02) *$ \\
\hline $\mathrm{AFQT}^{2}$ & & $-.05(.01) \star$ & $-.05(.01) \star$ & $-.09(.02) \star$ \\
\hline Pub. Support & & $-.16(.04) \star$ & $-.16(.04) \star$ & $-.14(.04) \star$ \\
\hline Pov. Status & & $-.21(.04) \star$ & $-.21(.04) \star$ & $-.02(.05)$ \\
\hline
\end{tabular}




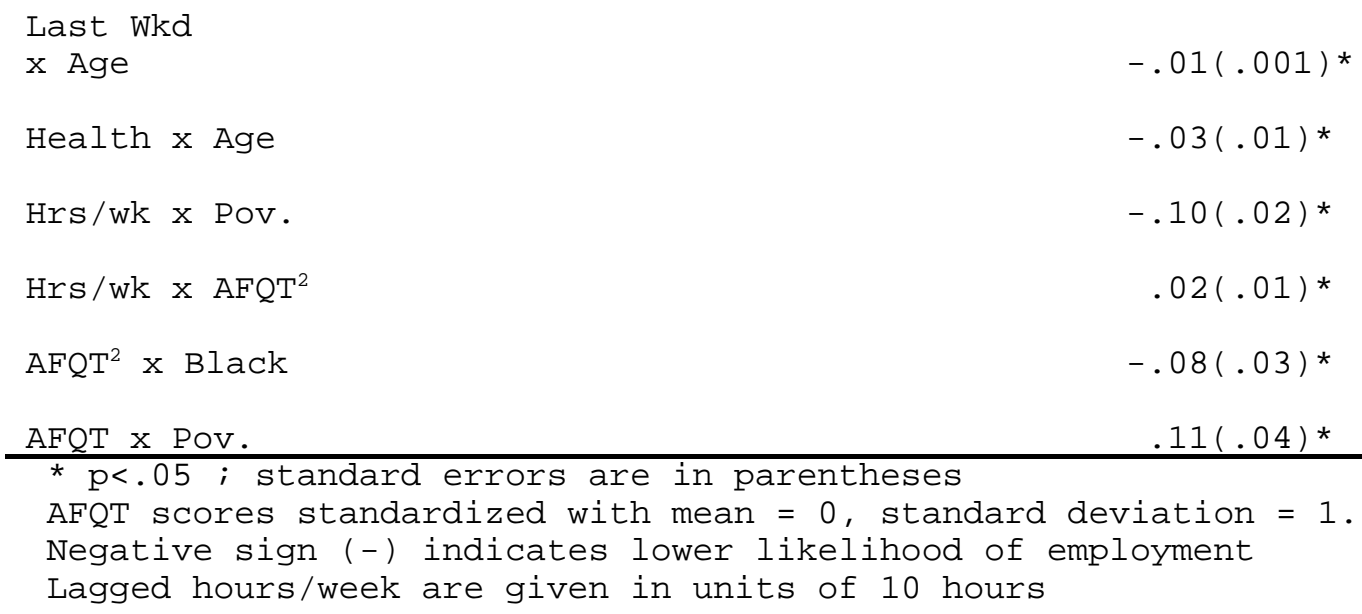


Table 5:

Prediction from Newborn Health

(Within-Family Fixed Effects) :

Sibling sample

\begin{tabular}{llllll}
\hline Mother's Has & By & By & By & By & By \\
$\begin{array}{l}\text { Entered } \\
\text { Labor Force: }\end{array}$ & Year 1 & Year 2 & Year 3 & Year 4 & Year 5 \\
& $\mathrm{n}=5727$ & $\mathrm{n}=5665$ & $\mathrm{n}=5602$ & $\mathrm{n}=5509$ & $\mathrm{n}=5420$ \\
\hline
\end{tabular}

\section{Ordinary}

Logistic:

\begin{tabular}{|c|c|c|c|c|c|}
\hline High Risk & $\begin{array}{l}-.20 \text { * } \\
(.09) \\
{[.81]}\end{array}$ & $\begin{array}{l}-.36 \\
(.09) \\
{[.70]}\end{array}$ & $\begin{array}{l}-.44 \\
(.09) \\
{[.64]}\end{array}$ & $\begin{array}{l}-.44 \\
(.10) \\
{[.64]}\end{array}$ & $\begin{array}{l}-.37 \\
(.11) \\
{[.69]}\end{array}$ \\
\hline Premature & $\begin{array}{c}.26 \\
(.10) \\
{[1.30]}\end{array}$ & $\begin{array}{c}.22 \\
(.11) \\
{[1.25]}\end{array}$ & $\begin{array}{c}.33 \\
(.12) \\
{[1.39]}\end{array}$ & $\begin{array}{c}.33 \\
(.13) \\
{[1.39]}\end{array}$ & $\begin{array}{c}.40 \text { (.15) } \\
{[1.49]}\end{array}$ \\
\hline
\end{tabular}

\section{Within- \\ family fixed \\ effects :}

High Risk

(.15)

$-.28$

(.16)

$-.49 \star$

$-.58 *$

$-.53 \star$

[.86]

[.75]

(.18)

$(.20)$

(.24)

[.61]

[.56]

[.59]

Premature

$\begin{array}{ccccc}.19 & .03 & -.03 & -.07 & .05 \\ (.17) & (.19) & (.22) & (.26) & (.32) \\ {[1.20]} & {[1.03]} & {[.97]} & {[.93]} & {[1.05]}\end{array}$

$\star \mathrm{p}<.05$

Standard errors are in parentheses: ( );

odds ratios are in brackets: [ ].

Ordinary Logistic: each model also includes child gender and the background variables included in the models presented in Table 3

Within-Family Fixed Effects (Conditional Logistic): each model also includes child gender (not significant), mother's age and health at child's birth, father's presence, interval since mother last worked before child's birth, and mother's hours/week of working (if any) in the fourth quarter before pregnancy. 
Table 6:

Prediction from Infant Development and Temperament

To the Timing of Mother's Entry to Employment:

(Proportional Hazard Models)

Development Sample

\begin{tabular}{|c|c|c|c|c|c|}
\hline & $\begin{array}{l}\text { Model } 1 \text { : } \\
\text { infant } \\
\text { factors } \\
\text { only } \\
n=2841\end{array}$ & $\begin{array}{l}\text { Model 2: } \\
\text { with } \\
\text { maternal } \\
\text { factors } \\
\mathrm{n}=2841\end{array}$ & $\begin{array}{l}\text { Model 3: } \\
\text { with } \\
\text { int'ns } \\
\mathrm{n}=2841\end{array}$ & $\begin{array}{l}\text { Model } 4: \\
\text { "not yet } \\
\text { working" } \\
\text { subgroup } \\
n=1162\end{array}$ & $\begin{array}{l}\text { Model } 5 \text { : } \\
\text { "not yet } \\
\text { working" } \\
\text { subgroup } \\
n=1162\end{array}$ \\
\hline High Risk & $\begin{array}{l}-.19 \star \\
(.06)\end{array}$ & $\begin{array}{l}-.07 \\
(.06)\end{array}$ & $\begin{array}{l}-.07 \\
(.06)\end{array}$ & $\begin{array}{l}.001 \\
(.10)\end{array}$ & $\begin{array}{c}.02 \\
(.10)\end{array}$ \\
\hline Preterm & $\begin{array}{c}.08 \\
(.07)\end{array}$ & $\begin{array}{c}.05 \\
(.07)\end{array}$ & $\begin{array}{c}.06 \\
(.07)\end{array}$ & $\begin{array}{r}-.13 \\
(.15)\end{array}$ & $\begin{array}{c}-.13 \\
(.14)\end{array}$ \\
\hline Female & $\begin{array}{l}.07 \\
(.04)\end{array}$ & $\begin{array}{l}.07 \\
(.04)\end{array}$ & $\begin{array}{c}.03 \\
(.04)\end{array}$ & $\begin{array}{l}.01 \\
(.07)\end{array}$ & $\begin{array}{l}-.00 \\
(.07)\end{array}$ \\
\hline $\begin{array}{l}\text { Dev'mnt } \\
2\end{array}$ & $\begin{array}{l}.09 \\
(.02)\end{array}$ & $\begin{array}{l}.08 * \\
(.02)\end{array}$ & $\begin{array}{l}.09 \\
(.02)\end{array}$ & $\begin{array}{l}.08 \text { * } \\
(.04)\end{array}$ & $\begin{array}{l}.08 \\
(.04)\end{array}$ \\
\hline Fear & $\begin{array}{l}-.09 \star \\
(.02)\end{array}$ & $\begin{array}{l}-.02 \\
(.02)\end{array}$ & $\begin{array}{c}.04 \\
(.03)\end{array}$ & $\begin{array}{l}-.13 \star \\
(.04)\end{array}$ & $\begin{array}{l}-.10 \\
(.06)\end{array}$ \\
\hline Diff. & $\begin{array}{l}-.02 \\
(.03)\end{array}$ & $\begin{array}{l}.08 * \\
(.03)\end{array}$ & $\begin{array}{c}.07 \\
(.05)\end{array}$ & $\begin{array}{l}.31 \\
(.05)\end{array}$ & $\begin{array}{l}.14 \\
(.06)\end{array}$ \\
\hline $\begin{array}{l}\text { Diff.x } \\
\text { Hours }\end{array}$ & & & $\begin{array}{c}.02 \\
(.02)\end{array}$ & & $\begin{array}{l}.10 \\
(.03)\end{array}$ \\
\hline $\begin{array}{l}\text { Diff.x } \\
\text { Hours } x \\
\text { Sex }\end{array}$ & & & $\begin{array}{l}-.04 \\
(.02)\end{array}$ & & $\begin{array}{l}-.10 \star \\
(.03)\end{array}$ \\
\hline $\begin{array}{l}\text { Diff. } x \\
\text { preterm }\end{array}$ & & & $\begin{array}{l}.21 \\
(.09)\end{array}$ & & $\begin{array}{l}.33 \\
(.16)\end{array}$ \\
\hline AFQT $x$ Sex & & & $\begin{array}{l}.11 * \\
(.04)\end{array}$ & & $\begin{array}{c}.07 \\
(.08)\end{array}$ \\
\hline $\begin{array}{l}\text { AFQT } x \\
\text { Fear }\end{array}$ & & & $\begin{array}{l}-.07 * \\
(.02)\end{array}$ & & $\begin{array}{l}-.05 \\
(.04)\end{array}$ \\
\hline
\end{tabular}




\begin{tabular}{|c|c|c|c|c|}
\hline $\begin{array}{l}\text { Log-Wks } \\
\text { Since }\end{array}$ & $\frac{-.13}{(.01)}$ & $\frac{-.13 \star}{(.01)}$ & $\frac{-.10}{(.02)}$ & $\begin{array}{l}-.09 \star \\
(.02)\end{array}$ \\
\hline $\begin{array}{l}\text { Lagged } \\
\text { Hrs/Wk }\end{array}$ & $\begin{array}{l}.05 \\
(.02)\end{array}$ & $\begin{array}{l}.05 \\
(.02)\end{array}$ & $\begin{array}{l}.02 \\
(.04)\end{array}$ & $\begin{array}{l}.03 \\
(.04)\end{array}$ \\
\hline Health & $\begin{array}{l}-.21 \\
(.05)\end{array}$ & $\begin{array}{l}-.21 \\
(.05)\end{array}$ & $\begin{array}{l}-.22 \star \\
(.09)\end{array}$ & $\begin{array}{l}-.23 \star \\
(.09)\end{array}$ \\
\hline Black & $\begin{array}{l}.31 \\
(.06)\end{array}$ & $\begin{array}{l}.30 * \\
(.06)\end{array}$ & $\begin{array}{c}.17 \\
(.10)\end{array}$ & $\begin{array}{c}.13 \\
(.11)\end{array}$ \\
\hline Hisp. & $\begin{array}{l}.16 \text { * } \\
(.06)\end{array}$ & $\begin{array}{l}.15 \\
(.06)\end{array}$ & $\begin{array}{l}.02 \\
(.10)\end{array}$ & $\begin{array}{l}-.02 \\
(.11)\end{array}$ \\
\hline Age & $\begin{array}{c}-.003 \\
(.01)\end{array}$ & $\begin{array}{c}-.009 \\
(.01)\end{array}$ & $\begin{array}{c}-.02 \\
(.01)\end{array}$ & $\begin{array}{l}-.02 \\
(.01)\end{array}$ \\
\hline $\mathrm{AFQT}$ & $\begin{array}{l}.16 \text { * } \\
(.03)\end{array}$ & $\begin{array}{l}.13 \text { * } \\
(.04)\end{array}$ & $\begin{array}{c}.09 \\
(.05)\end{array}$ & $\begin{array}{l}.06 \\
(.06)\end{array}$ \\
\hline $\mathrm{AFQT}^{2}$ & $\begin{array}{c}-.06 \\
(.02)\end{array}$ & $\begin{array}{l}-.06 \\
(.02)\end{array}$ & $\begin{array}{c}-.17 \\
(.04)\end{array}$ & $\begin{array}{c}-.16 \\
(.04)\end{array}$ \\
\hline $\begin{array}{l}\text { Poverty } \\
\text { Status }\end{array}$ & $\begin{array}{l}-.22 \\
(.06)\end{array}$ & $\begin{array}{l}.01 \\
(.01)\end{array}$ & $\begin{array}{l}.006 \\
(.10)\end{array}$ & $\begin{array}{l}.02 \\
(.10)\end{array}$ \\
\hline $\begin{array}{l}\text { Firstbor } \\
\mathrm{n}\end{array}$ & $\begin{array}{c}-.04 \\
(.04)\end{array}$ & $\begin{array}{c}-.01 \\
(.04)\end{array}$ & $\begin{array}{l}-.29 \\
(.09)\end{array}$ & $\begin{array}{l}-.27 \\
(.09)\end{array}$ \\
\hline $\begin{array}{l}\text { Public } \\
\text { Support }\end{array}$ & $\frac{-.18}{(.07)}$ & $\begin{array}{l}-.26 \star \\
(.07)\end{array}$ & $\begin{array}{l}-.32 \\
(.12)\end{array}$ & $\begin{array}{l}-.32 \text { * } \\
(.12)\end{array}$ \\
\hline $\begin{array}{l}\text { Partner } \\
\text { in Home } \\
\text { Yr } 0\end{array}$ & $\begin{array}{l}.01 \\
(.06)\end{array}$ & $\begin{array}{l}.05 \\
(.05)\end{array}$ & $\begin{array}{r}-.06 \\
(.11)\end{array}$ & $\begin{array}{c}-.08 \\
(.11)\end{array}$ \\
\hline
\end{tabular}

$\star \mathrm{p}<.05$

"Not yet working" subgroup = those infants whose mothers are not yet working at time of assessment. $\mathrm{AFQT}$, development and temperament scores are standardized such that mean $=0$, standard deviation $=$ 1 .

Lagged Hours per week expressed in units of 10 hours Negative sign (-) indicates lower likelihood of employment; standard errors are in parentheses. 


\begin{tabular}{|c|c|c|c|c|c|c|}
\hline \multirow[b]{2}{*}{$\mathrm{n}=1807$} & \multirow{2}{*}{$\begin{array}{l}\text { Model } 1 \\
\text { with } \\
\text { selected } \\
\text { background } \\
\text { factors }\end{array}$} & \multirow{2}{*}{$\begin{array}{l}\text { Model } 2 \\
\text { includes } \\
\text { lagged } \\
\text { work, } \\
\text { health, } \\
\text { AFQT }\end{array}$} & \multirow{2}{*}{\multicolumn{2}{|c|}{$\begin{array}{l}\text { Model } 3 \\
\text { with } \\
\text { child } \\
\text { factors } \\
\text { except } \\
\text { difficult } \\
\text { temperame } \\
\text { nt }\end{array}$}} & \multirow{2}{*}{\multicolumn{2}{|c|}{$\begin{array}{l}\text { Model } 4 \\
\text { with } \\
\text { difficult } \\
\text { temperamen } \\
t\end{array}$}} \\
\hline & & & & & & \\
\hline Average & $.47 \star$ & $.59 \star$ & .71 & * & .61 & * \\
\hline $\begin{array}{l}\text { Hours Worked } \\
\text { by } 4 \text { years } \\
\text { (one unit = } \\
10 \text { hrs) }\end{array}$ & $(.23)$ & $(.26)$ & $(.26)$ & & $(.25)$ & \\
\hline Child=Female & & & $\begin{array}{r}-2.18 \\
(.67)\end{array}$ & * & $\begin{array}{r}-1.85 \\
(.66)\end{array}$ & $\star$ \\
\hline $\begin{array}{l}\text { Child=High } \\
\text { Risk }\end{array}$ & & & $\begin{array}{l}1.66 \\
(.96)\end{array}$ & & $\begin{array}{l}1.55 \\
(.94)\end{array}$ & \\
\hline Development & & & $\begin{array}{r}-1.22 \\
(.34)\end{array}$ & * & $\begin{array}{r}-.77 \\
(.34)\end{array}$ & $\star$ \\
\hline Fearfulness & & & $\begin{array}{l}1.14 \\
(.36)\end{array}$ & * & $\begin{array}{l}.81 \\
(.35)\end{array}$ & $\star$ \\
\hline Difficulty & & & & & $\begin{array}{l}3.75 \\
(.47)\end{array}$ & $\star$ \\
\hline $\begin{array}{l}\text { Lagged } \\
\text { Hours/Week }\end{array}$ & & $\begin{array}{l}.41 \\
(.33)\end{array}$ & $\begin{array}{l}.35 \\
(.33)\end{array}$ & & $\begin{array}{l}.39 \\
(.32)\end{array}$ & \\
\hline $\begin{array}{l}\text { Log-Wks } \\
\text { Since Last } \\
\text { Worked }\end{array}$ & & $\begin{array}{l}.12 \\
(.18)\end{array}$ & $\begin{array}{l}.09 \\
(.18)\end{array}$ & & $\begin{array}{l}.09 \\
(.17)\end{array}$ & \\
\hline
\end{tabular}




\begin{tabular}{|c|c|c|c|c|c|c|c|}
\hline $\begin{array}{l}\text { Mother's } \\
\text { AFQT }\end{array}$ & & & $\begin{array}{r}-2.20 \star \\
(.41)\end{array}$ & $\begin{array}{r}-2.03 \\
(.41)\end{array}$ & $\star$ & $\begin{array}{r}-1.65 \\
(.41)\end{array}$ & * \\
\hline $\mathrm{AFQT}^{2}$ & & & $\begin{array}{c}.90 \star \\
(.33)\end{array}$ & $\begin{array}{l}.88 \\
(.32)\end{array}$ & $\star$ & $\begin{array}{l}.68 \\
(.32)\end{array}$ & $\star$ \\
\hline Mom has & & & $\begin{array}{r}3.31 \star \\
(.86)\end{array}$ & $\begin{array}{l}3.35 \\
(.86)\end{array}$ & $\star$ & $\begin{array}{l}3.53 \\
(.84)\end{array}$ & * \\
\hline $\begin{array}{l}\text { Health } \\
\text { Problem }\end{array}$ & $\begin{array}{r}-.46 \\
(.12)\end{array}$ & $\star$ & $\begin{array}{r}-.34 \star \\
(.13)\end{array}$ & $\begin{array}{l}-.32 \\
(.13)\end{array}$ & $\star$ & $\begin{array}{l}-.29 \\
(.12)\end{array}$ & * \\
\hline & $\begin{array}{l}5.53 \\
(.85)\end{array}$ & * & $\begin{array}{r}3.36 \star \\
(.92)\end{array}$ & $\begin{array}{l}3.07 \\
(.91)\end{array}$ & $\star$ & $\begin{array}{l}2.60 \\
(.90)\end{array}$ & * \\
\hline $\begin{array}{l}\text { Poverty } \\
\text { Status }\end{array}$ & $\begin{array}{l}.64 \\
(.76)\end{array}$ & & $\begin{array}{l}.85 \\
(.76)\end{array}$ & $\begin{array}{l}1.33 \\
(.76)\end{array}$ & & $\begin{array}{l}1.44 \\
(.75)\end{array}$ & * \\
\hline Firstborn & & & & & & & \\
\hline $\begin{array}{l}\text { Adjusted R- } \\
\text { square }\end{array}$ & .036 & & .063 & .083 & & .11 & \\
\hline
\end{tabular}

${ }^{*} \mathrm{p}<.05 ;$ Standard errors are in parentheses. Except for infant "high risk" status and lagged employment, variables were kept in final model only if significant. 


\section{APPENDIX A: Definitions of newborn health variables}

Although prematurity and intrauterine growth retardation are often considered together, as components of "low birthweight", the causes and developmental consequences of the two factors may be different (Cogswell and Yip, 1995). Premature infants are at higher risk of neurological and other complications in the early newborn period, but those premature infants who survive the perinatal period without complications seem to have few long term developmental problems. In contrast, both full term and preterm infants with intrauterine growth retardation or perinatal complications appear to be at long term risk for learning disabilities, disruptive behavior disorders, and attention deficit disorder ( Walther, 1988; Villar et al, 1984; Hadders-Algra and Touwen, 1990; and McCarton et al, 1996). Prematurity and intrauterine growth retardation are considered separately in the present study.

\section{Prematurity:}

In general, gestational age is measured less accurately than birth weight. The gestational ages in the NLSY are calculated from a question asking how many weeks early or late the child was born, compared to the child's expected due date; this number was then added to or subtracted from 39 weeks. This method seems to have resulted in some "heaping", with too few births reported at 38 and 40 weeks, and too many at 39 weeks, but the distribution of gestational ages before 38 weeks and after 40 weeks seems to be otherwise similar to the distribution reported in US 
national vital statistics. (US Vital Statistics, 1990).

We have used a conventional cutoff of 37 weeks' gestation to define prematurity; $11.6 \%$ of children in the present sample were reported to have been born earlier than 37 weeks; $10.6 \%$ of all births were reported to occur before 37 weeks in the United States in 1990. The results presented were qualitatively unchanged by the use of a continuous measure, or by the use of other cutoffs, ranging from 32 to 36 weeks.

\section{Intrauterine growth retardation (IUGR):}

Infants with IUGR represented 54\% of the low birth-weight infants in the present sample. In general, infants with IUGR have higher rates of perinatal morbidity and mortality than normal weight infants of comparable gestational ages; IUGR infants appear to be at higher risk for minor neurological dysfunction, cognitive delays and behavioral problems, compared to normal weight infants (Villar et al, 1984; Hadders-Algra and Touwen, 1990; McCarton et al, 1996).

For the purposes of this report, infants were classified as having intrauterine growth retardation (IUGR) if they fell below a standard criterion of weight for gestational age, categorized separately for boys and girls, and for black versus other infants (Hoffman et al, 1974). About 5.8\% of infants in the sample were classified as IUGR. The "heaping" of gestational age at 39 weeks in the NLSY has probably introduced some error in the classification of infant nutritional status, with some infants actually born at 38 weeks being overclassified as IUGR, 
and some infants actually born at 40 weeks being underclassified; nevertheless, the overall proportion of IUGR appears to be comparable to the rates reported in other recent studies. As with prematurity, other criteria (including the simple use of birthweight) yielded qualitatively similar results. A SAS program to calculate IUGR status using the Hoffman tables is available from the author.

\section{Birth Defect:}

Until 1991, mothers in the NLSY were asked whether they had had a sonogram or amniocentesis during pregnancy, and, if so, they were asked for the results of the test. 104 infants in the sample (1.6\%) were given a prenatal diagnosis of "birth defect" from one of these tests; 18 of these infants were eventually born prematurely and 86 were born at term. This category may not capture all of the infants in the sample with congenital anomalies: the question was not asked after the 1990 survey, and the question does not include infants whose diagnosis was made at the time of birth or later. The pattern of results presented here remains unchanged if we consider only children born before 1991.

\section{Extended hospitalization at birth:}

Complications of birth and a wide range of other prenatal or perinatal health problems may also carry long term risks for cognitive and behavioral problems (McCarton 1996). 
The length of the child's hospitalization at birth is a non-specific measure reflecting both the infant's health status and, of course, current health care practices. We control for differences in the average length of stay for a normal delivery, and for infants who are boarded for extra days because of the requirements of mother's recovery, by comparing the child's length of stay in the hospital with mother's length of stay. Newborns were categorized as having "extended hospitalization" if the child stayed in the hospital longer than mother, or for more than seven days.

By this definition, $11 \%$ of infants in the sample, representing $38.3 \%$ of premature infants, $29.4 \%$ of IUGR infants, $16.4 \%$ of infants with birth defects, and $6.9 \%$ of full term and normal weight infants, had extended hospitalizations. Again, results were qualitatively unchanged by using other cutoffs, or by using a continuous rather than a categorical measure.

\section{APPENDIX B:}

\section{Maternal background factors:}

Ten maternal background factors were included in the labor supply models present here. All factors refer to information collected before the child's birth.

The strongest predictor of mother's return to employment after the child's birth was mother's history of past employment. As indicators of mother's attachment to the labor force, we use mother's hours per week of employment in the fourth quarter (9 to 12 months) before the child's birth, ("hours/week before 
pregnancy"), and the log of the time since mother has last been employed, if she was not working in the fourth quarter before the child's birth ("log weeks since last worked before pregnancy"). Employment in the fourth quarter before birth represents employment observed just before conception; it is the most recent observation of mother's employment prior to the possible effects of the pregnancy itself.

We also include several other conventional factors predicting mother's expected wage, (mother's AFQT, black and hispanic ethnicity, age, and mother's health status before pregnancy), the existing demand for mother's household production (the child's birth order), and the availability of other sources of income or support (whether the household fell below federal poverty status level in the year before the child's birth; spouse or partner's presence in the home; and the family's receipt of AFDC, SSI, or food stamps in the year before the child's birth). Although maternal employment rates in the United States were increasing throughout the period of the survey, the child's year of birth, and the local unemployment rate in the year of the child's birth, were not significant predictors of the timing of mother's employment in the present study, and were omitted from the final models.

"Mother's health" refers to mother's self-reported health status in the most recent interview before the child's birth; the variable is recorded as 1 if mother reported having a health condition that would limit her ability to work, the type of work she was able to do, or the hours per week that she would be able to work. If 
mother reported no health problem, or if the only health condition mentioned was pregnancy, the variable was recorded as zero. Two other possible maternal health factors (cesarean section delivery, and length of mother's hospitalization at birth) did not directly predict mother's employment, and were not included in the analysis.

The Armed Forces Qualifications Test (AFQT) is a measure of verbal aptitude, derived from mother's Profile scores on the Armed Services Vocational Aptitude Battery, administered to all NLSY respondents in 1980. Although the AFQT score is influenced by educational exposure, age at testing, and language background, and should not be thought of as an unbiased measure of "true intelligence", the AFQT has been found to be a powerful predictor of later educational attainment, wages, and income; mother's AFQT is also a powerful predictor of the child's cognitive development (eg, Hill and O'Neill, 1994).

The AFQT score is represented in the regression models as a $\mathrm{z}$-score, with a mean of zero and a standard deviation of one; a quadratic relationship between AFQT score and maternal employment is represented by squaring the standardized score. 


\section{$\underline{\text { References }}$}

Angrist, J. and Evans, W.N. (1996) "Children and their Parents' Labor Supply: Evidence from Exogenous Variation in Family Size" NBER Working Paper \#5778 National Bureau of Economic Research, Inc. Cambridge, MA

Baydar, N. and Brooks-Gunn, J. (1991) "Effects of Maternal Employment and Child Care Arrangements on Preschoolers Cognitive and Behavioral Outcomes: Evidence from the National Longitudinal Survey of Youth" Developmental Psychology 27(6):932-945

Becker, G. and Lewis, H. Gregg (1973) "On the Interaction between the Quantity and Quality of Children" Journal of Political Economy 81(2,2):S279-S288

Becker, G. and Tomes, N. (1976) "Child Endowments and the Quantity and Quality of Children" Journal of Political Economy 84(4):S143-S162

Bell, R.Q. (1971) "Stimulus Control of Parent or Caretaker Behavior by Offspring" Develpm. Psychol. 4:63-72

Belsky, J. and Eggebeen D. (1991) "Early and Extensive Maternal Employment and Young Children's Socioemotional Development: Children of the National Longitudinal Survey of Youth"

Journal of Marriage and the Family 53:1083-1110

Blau, D. and Hagy, A. (1998) "The Demand for Quality in Child Care" Journal of Political Economy 106(1):104-146

Blau, F. and Grossberg. A. (1992) "Maternal Labor Supply and Children's Cognitive Development" Review of Economics and Statistics 74:474-481

Breslau, N., Salkever, D., and Staruch, K.S.(1982) "Women's Labor Force Activity and Responsibilities for Disabled Dependents: A Study of Families With Disabled Children" Journal of Health and Social Behavior, 23:169-183

Bronfenbrenner, U., Alvarez, W. and Henderson, C (1984) "Working and Watching: Maternal Employment Status and Parents' Perceptions of Their ThreeYear-Old Children" Child Development 55:1362-1378

Burchinal, M., Campbell, F., Bryant, D., Wasick, B. and Ramey, C. (1997) "Early Intervention and Mediating Processes in Cognitive Performance of Children of Low-Income African American Families" Child Development 68(5):935-954 
Burchinal, M., Lee, M. and Ramey, C. (1989) "Type of Day-Care and Preschool Intellectual Development in Disadvantaged Children" Child Development 60:128-137

Caldwell, B. (1993) "Impact of Day Care on the Child" Pediatrics 91(1):225-228

Center for Human Resource Research NLS User's Guide 1994 Columbus, Ohio: Ohio State University

Center for Human Resource Research NLSY Child Handbook Columbus, Ohio: Ohio State University

Chase-Lansdale, P., Michael, R. and Desai, S. (1991) "Maternal Employment During Infancy: An Analysis of "Children of the National Longitudinal Survey of Youth"" from : Lerner \& Galambos (eds) Employed Mothers and Their Children New York: Garland

Clark, R., Hyde, J.S., Essex, M.J., and Klein, M.H. (1997) "Length of Maternity Leave and Quality of Mother-Infant Interactions" Child Development 68(2):364383

Cogswell, M and Yip, R. (1995) "The Influence of Fetal and Maternal Factors on the Distribution of Birthweight" Seminars in Perinatology 19:222-240

Corman, H. and Kaestner, R. (1992) "The Effects of Child Health on Marital Status and Family Structure" Demography 29(3):389-408

Desai, S., Chase-Lansdale, P., and Michael, R. (1989) "Mother or Market? Effects of Maternal Employment on the Intellectual Ability of 4 year old Children" Demography 26(4):545-561

Donovan, W.L., Leavitt, L.A. and Walsh, R.O.(1997) "Cognitive Set and Coping Strategy Affect Mothers' Sensitivity to Infant Cries: A Signal Detection Approach" Child Development, 68(5):760-772

Economic Report of the President, 1997 Table B3

Egeland, B. and Hiester, M.(1995) "The Long-Term Consequences of Infant DayCare and Mother-Infant Attachment" Child Development 66, pp 474-485

Galambos, N. and Lerner, J. (1987) "Child Characteristics and the Employment of 
Mothers with Young Children: A Longitudinal Study" J. Child Psychol.

Psychiatr. 28(1):87-98

Gamble, T. J.and Zigler, E. (1986) "Effects of Infant Day Care: Another Look at the Evidence"

Am J. Orthopsychiatr. 56(1):26-42

Goldsmith, H.H. and Alansky, J.A. (1987) "Maternal and Infant Temperamental Predictors of Attachment: A Meta-Analytic Review" J Consult Clin Psychol 55(6):805-816

Gorman, K.S.and Pollitt, E. (1992) "Relationship Between Weight and Body Proportionality at Birth, Growth During the First Year of Life, and Cognitive Development at 36, 48, and 60 Months"

Infant Behavior and Development 15:279-296

Greenberger, E. and O'Neil, R (1992) "Maternal Employment and Perceptions of Young Children: Bronfenbrenner et al. Revisited" Child Development 63:431-448

Hadders-Algra,M. and Touwen, B.C.L. (1990) "Body Measurements, Neurological and Behavioural Development in Six-Year-Old Children Born Preterm and/or Small-for-Gestational-Age" Early Human Development 22:1-13

Hanushek, E. (1992) "The Trade-off between Child Quantity and Quality" Journal of Political Economy 100(1):84-117

Hill, M. and O'Neill, J. (1994) "Family Endowments and the Achievement of Young Children with Special Reference to the Underclass" Journal of Human Resources 29(4):1064-2000

Hoffman, L. (1989) "Effects of Maternal Employment in the Two-Parent Family" American Psychologist 44(2):283- 292

Hoffman, H., Stark, C., Lundin, F., and Ashbrook, J.D. (1974) "Analysis of Birth Weight, Gestational Age, and Fetal Viability, U.S. Births, 1968" Obstetrical and Gynecological Survey 28(9):651-681

Lamb, M., Sternberg, K. and Prodromidis, M. (1992) "Nonmaternal Care and the Security of Infant-Mother Attachment: A Reanalysis of the Data" Infant Behavior and Development 15:71-83

Landis, L. J. (1992) "Marital, Employment, and Childcare Status of Mothers with Infants and Toddlers with Disabilities" Topics in Early Childhood Special 
Lester, B., Garcia-Coll, C., Valcarcel, M., Hoffman, J. and Brazelton, T.B., (1986) "Effects of Atypical Patterns of Fetal Growth on Newborn (NBAS) Behavior" Child Development 57(1):11-19

Mason, K.O. and Kuhlthau, K. (1992) "The Perceived Impact of Child Care Costs On Women's Labor Supply And Fertility" Demography 24(4):523-...

Maynard-Smith, J. (1977) "The Theory of Games and the Evolution of Animal Conflicts" J. Theor. Biol. 47:209-221

McCartney, K., and Rosenthal, S. (1991) "Maternal Employment Should Be Studied Within Social Ecologies" Journal of Marriage and the Family 53:1103-1107

McCarton, C. M., Wallace, I.F., Divon, M. and Vaughan, H. (1996) "Cognitive and Neurological Development of the Premature, Small for Gestational Age Infant Through Age 6: Comparison by Birth Weight and Gestational Age" Pediatrics 98(6):1167-1178

McGee, R., Silva, P. and Williams, S. (1984) "Perinatal, Neurological, Environmental and Developmental Characteristics of Seven-year-old Children With Stable Behaviour Problems" J. Child Psychol. Psychiatr. 25(4):573-586

Mott, F. "Developmental Effects of Infant Care: The Mediating Role of Gender and Health" (1991) Journal of Social Issues 47(2):139-158

NICHD Early Child Care Research Network (1997) "The Effects of Infant Child Care on Infant-Mother Attachment Security: Results of the NICHD Study of Early Child Care" Child Development 68(5):860-879

O'Brien-Caughy, M., DiPietro, J. and Strobino, D. (1994) "Day-Care Participation as a Protective Factor in the Cognitive Development of Low-Income Children" Child Development 65:457-471

Rosenzweig, M. and Schultz, P. (1983) "Estimating a Household Production Function: Heterogeneity, the Demand for Health Inputs, and Their Effects on Birth Weight" Journal of Political Economy 91(5):723-746

Rosenzweig, M. and Wolpin, K. (1988) "Heterogeneity, Intrafamily Distribution, and Child Health" Journal of Human Resources 23(4):437-461 
Rutter, M. (1981)"Social-Emotional Consequences of Day Care for Preschool Children" Am J Orthopsychiatry 51(1):4-28

Rutter, M. and Plomin, R. (1997) "Opportunities for Psychiatry from Genetic Findings" Br.J.Psychiatry 171:209-219

Salkever, D.S. (1979) "Children's Health Problems and Maternal Work Status" Journal of Human Resources 12:95-109

Scarr, S. (1991) "On Comparing Apples and Oranges and Making Inferences about Bananas" Journal of Marriage and the Family $\quad$ 53:1099-1100

Thomas, D. (1990) "Intrahousehold Resource Allocation: An Inferential Approach" Journal of Human Resources 25(4):635-664

Trivers, R. (1974) "Parent Offspring Conflict" American Zoologist 14:249--264

United States Department of Health and Human Services, National Center for Health Statistics (1990) Vital Statistics of the United States, Volume 1- Natality

Vandell, L. and Ramanan, J. (1992) "Effects of Early and Recent Maternal Employment on Children from Low-Income Families" Child Development 63:938-949

Vaughn, B., Gove, F. and Egeland, B. (1980) "Relationship between Out-of-Home Care and the Quality of Infant-Mother Attachment in an Economically Disadvantaged Population" Child Development 51:1203-1214

Villar, J., Smeriglio, V., Martorell, R., Brown, C.H., and Klein, R.E. (1984) "Heterogeneous Growth and Mental Development of Intrauterine Growth-Retarded Infants During the First 3 Years of Life" Pediatrics 74(5):783-791

Weinberg, M.K. and Tronick, E.Z. (1998) "The Impact of Maternal Psychiatric Illness on Infant Development" J Clin Psychiatry 59(supp 2):53-61

Wolfe, B., and Hill, S. (1993) "The Effect of Health on the Work Effort of Single Mothers" Journal Of Human Resources 30(1):43-62

Youngblut, J., Loveland-Cherry, C. and Horan, M. (1991) "Maternal Employment Effects on Family and Preterm Infants at Three Months" Nursing Research 40(5):272-275 
Zazlow, M., Rabinovich, B., and Suwalsky, J. (1991) "From Maternal Employment to Child Outcomes: Preexisting Group Differences and Moderating Variables" in: Lerner and

Galambos (eds): Employed Mothers and Their Children NY: Garland Press

Zeskind, P. and Ramey, C. (1978) "Fetal Malnutrition: An Experimental Study of Its Consequences on Infant Development in Two Caregiving Environments" Child Development 49:1155-1162 